\title{
Identification of Customer Loyalty Determinants in Service Industry
}

\author{
Saul Ronald Jacob Saleky ${ }^{1, *}$, Lee Cheng Wen' , Otto Randa Payangan ${ }^{3}$, Jusni ${ }^{3}$, Maat Pono \\ ${ }^{1}$ Doctor Candidate, Fakultas Ekonoi dan Bisnis, Universitas Hasanuddin, Makassar, Indonesia \\ ${ }^{2}$ Business College, Chung Yuan Christian University, Taiwan \\ ${ }^{3}$ Fakultas Ekonomi dan Bisnis, Universitas Hasanuddin, Makassar, Indonesia \\ *Corresponding author: saulsaleky@gmail.com
}

Received August 25, 2018; Revised October 10, 2018; Accepted November 19, 2018

\begin{abstract}
In the context of an increasingly competitive industry, customer loyalty is seen as a key factor in winning company. Forming a loyal customer is an important thing for company management. This article is a literature review of the factors that are the determinants of customer loyalty in the service industry. Through this article, the authors attempt to identify the various factors that are determinants of customer market share and to develop a sustainable competitive advantage. Customer's loyalty is one key to the success in the service industry.
\end{abstract}

Keywords: customer loyalty, satisfaction, commitment, trust, satisfaction, brand equity, service quality, perceived price, customer perceived value

Cite This Article: Saul Ronald Jacob Saleky, Lee Cheng Wen, Otto Randa Payangan, Jusni, and Maat Pono, "Identification of Customer Loyalty Determinants in Service Industry." Journal of Business and Management Sciences, vol. 6, no. 4 (2018): 171-178. doi: 10.12691/jbms-6-4-5.

\section{Introduction}

Organizations today face the challenges of a diverse and extraordinary. Therefore organizations must manage the uncertainty of the environment in order to be effective [1]. In the face of competition and limited resources, the marketers shifting their focus from efforts to gain new customers on the efforts to retain existing customers, and of completing the deal "one shot" into securing customers' lifetime value $[2,3]$.

Therefore, in the context of an increasingly competitive industry, customer loyalty is seen as a key factor in winning market share and to develop a sustainable competitive advantage. In the service industry, a typical feature requires an understanding of customer service, satisfying the needs and expectations, create, communicate and deliver customer value, and keeping promises [4].

Loyal customers are believed to be an asset for marketers, because the loyalty expected to persist in the long term. With the loyal customer, business marketers to find and develop new customers will be reduced. Has long been recognized that efforts to get new loyal customer takes effort and cost you a bit [5,6,7,8].

Loyal customers will have an impact on repeat purchases, word of mouth recommendations, and customer resistance. Customer loyalty is the customer's intention to re-use the products offered marketers based on experience and their expectations in the past [9]. Loyalty is also a psychologically deep commitment to buy consistently repeated in the future despite attractive offers from competitors to switch brands. In this context, the fundamental question is how to create loyal customers, as well as what are the factors that affect customer loyalty? Understanding why or how customer loyalty continues to be one of the issues that are important marketing management services to date [10].

This article is a literature review of the factors that are the determinants of customer loyalty in the service industry. Empirical research on customer loyalty has been a lot done. However until now still not reached a consensus on the key factors that shape the loyalty of customers $[11,12,13,14,15]$ showed that the main factor for the formation of a very complex and dynamic loyalty because customers are constantly changing and evolving over time. Therefore, Knox \& Walker [13] suggested that need more research on this. A number of research shows that there are several factors that are antecedents of customer loyalty. In this article the variables that will be studied as a determinant of customer loyalty is the quality of service, price perception, the perception of value, brand equity, customer satisfaction, customer trust and customer commitment.

\section{Literature Review}

\subsection{Service Quality}

To achieve customer satisfaction, quality of service is an important determinant to be considered by the service provider. Because of the quality of the received or perceived as customer perception of overall quality or excellence of a product or service that is pleased with the intention expected. Quality of service related to customer 
satisfaction. Correspondingly, the Rial et al. [16] stated that the quality of support services is very strong impact on satisfaction with the service provider. Thus, service providers should always be open and always learn to what the customer wants. If this is true then the customer satisfaction will be achieved. Empirical research Ravichandran et al. [17], Dai et al. [18], Shlash \& Alhamdani [19], Mohammad \& Alhamadani [20], Hu [21], Rahman et al. [22], Shpëtim [23], Zafar et al. [24], Ramseook-Munhurrun [25], as well as Madjid et al. [26] showed that customer loyalty can also be influenced by the quality of service.

\subsection{Perceived Price}

While the products, distribution, and promotion resulted in the expenditure of resources, the price is one of the elements of the marketing mix that directly affect the inflow of resources. For this reason, the activity is important for managers to organize and manage the price. To manage effective pricing decisions, marketing managers must seek to understand how consumers respond to price changes. For customers, the perceived price, which includes the time, effort and cost of the search, is more meaningful than the actual monetary price of goods and services. Customers usually as a judge in deciding the price and quality of service as well as generating satisfaction or dissatisfaction levels are based on the concept of "equity" [27]. In other words, in the evaluation of the reasonableness of the overall price, customers consider cost of the monetary and non-monetary acquire products or services [28,29,30].

Previously, Fornell, et al. [11] suggested that affects price perceptions of customer satisfaction. Similarly, Voss, et al. [31] suggested that satisfaction affects price perceptions. In addition, other studies also indicate that price is considered to be very important in determining the duration of the provider-customer relationship [32]. Because it can be said that the perception of price is one of the determinants of satisfaction, trust, commitment and customer loyalty [11,31,32].

\subsection{Customer Perceived Value}

Other factors that affect consumer loyalty is the value received by the consumer in any transactions with service providers. No high-value services by itself but must go through the process of creating value from the consumer. Customer value is a sense of joy and consumer evaluation of the product attributes, attributes of performance, and the consequences arising out of the use of facilities in achieving the goals and intentions of consumers in the situation that connect the product situation and consequences related to that experienced by consumers who are goal-oriented [33].

Values can be seen from a different perspective, from the perspective of normative-marketing strategies and consumer behavior-descriptive perspective. In a normative perspective of marketing strategy, customer value creation is one of the key elements for the success of a company. Meanwhile, from the perspective of consumer behavior descriptive, value is something desirable, useful or important. Therefore, people will be able to achieve some of their personal value through the possession or consumption of the product [34,35]. In this context, consumers buy products not for the sake of "transaction value" (the value of customers) but for the benefit of products that will satisfy their needs or personal values.

Customer value is a consequence of the subjective evaluation which is the sum of a variety of perceived benefits and costs, taking into account different factors. In other words, the perceived value of customers is the surplus (or difference) between the perceived benefits and costs, which refers to the subjective rate of return for the cost of customer perceived. Therefore, to establish customer loyalty is high, then a company must be able to deliver high customer value as well.

\subsection{Brand Equity}

Brand equity is a series of brand assets and liabilities associated with a brand name and symbol that add or subtract a given value of a product or service to the company [5]. From this perspective, brand equity is formulated from the standpoint of managerial and corporate strategy, although the main foundation is consumer behavior. According to him, the brand equity can be valuable for the company (company-based brand equity) and the customer (customer-based brand equity). Services brand equity has been recognized as an important marketing construct. To create loyalty, one of which must be owned by the company is to build a strong brand that consumers always faithful [36]. An important reason for managing and developing their brand equity is more brand more meaningful than just products. Product dimensions only describes the attributes to be exchanged and easily imitated by other companies, while brand can explain the specific emotions and relationships with customers as well as the nature of intangible (intangible) that are not easily copied by competitors. The stronger the brand equity of a product, the stronger the appeal in the eyes of the consumer to choose the product motivated. To foster brand loyalty. If consumers believe that a particular brand is physically different from competing brands, the brand image will be attached on an ongoing basis so as to form a loyalty to a particular brand, which in turn will create customer loyalty [37].

Brand equity also affect the attitude and the confidence of consumers in making purchasing decisions, either because of past experiences in using the brand, as well as proximity to the brand and the various characteristics possessed by the brand. Brand equity is empirically also a determining factor of satisfaction, trust, commitment and customer loyalty [38-46].

\subsection{Customer Satisfaction}

To realize that loyal customers, it is necessary to customer satisfaction. In other words, a satisfied customer will tend to be loyal. Correspondingly, the satisfaction of having a close relationship with the level of loyalty. However, the reality in the market shows that consumers are satisfied it is difficult to be loyal. Some results of empirical research shows that the tendency to make the shift more brands carried by consumers satisfied. This shows that the satisfaction and loyalty do not have a 
strong influence linearly to the same degree. That is, consumers are satisfied are not necessarily loyal.

In the context of a relationship, customer satisfaction resulting from a thorough evaluation of the services offered. The satisfaction of having a role in the formation of loyalty as satisfaction will strengthen the positive attitude of consumers who will direct them to a greater likelihood to repurchase the same products or services [47]. According to Verhoef [48] as the emotional nuances of satisfaction is the result of interaction with the company all the time. These emotional states must be maintained and upgraded by the service provider. Customer satisfaction is important for long-term success of the company [49]. Satisfaction is not enough if consumers are not turning back or be loyal.

\subsection{Customer Trust}

Trust is a desire to maintain the exchange because it is believed [50]). The essence of trust is confidence. Confidence arises because both parties believe that they will be trustworthy, have integrity, consistent, competent, fair, responsible, helpful, and a number of other positive properties. Trust more emphasis on the psychological state of a person to accept what is on the behavior of others, based on trust or positive expectations on him [51]. Meanwhile, Nicholson et al. [52] suggested that trust is a positive expectation on other parties in a risky situation, and trust can serve as a foundation based on any cooperation.

Trust has the basic elements of such trust in a partner or the other, based on the belief that positive expectations (without suspicion), and the relationship to risk between the two parties. Similarly, trust is also a desire to maintain a trusted partner [53]. Therefore, trust is an important factor contributing to the development of relations and will affect customer satisfaction due to the marketing relationship [54].

\section{Discussion}

\subsection{Relationship of Service Quality with Satisfaction, Trust, Commitment and Loyalty}

Has long been recognized that the quality of service is an antecedent of the concept of customer satisfaction wider $[55,56,57,58]$, and the relationship between quality of service and loyalty mediated by satisfaction $[59,60]$. Customer satisfaction is the evaluation of the overall service. This is a reflection of customers in making their purchases earlier. Customer satisfaction on quality services that will have the trust, commitment and loyalty over the service provider, and the products or services offered.

Some findings empirically that shows the relationship between quality of service and satisfaction, trust, commitment and loyalty of which is the result of research conducted by the Hadioetomo [61], Hatane and Wijaya [62], Hamadi [63], Yee \& Faziharudean [64], Deng et al. [65], Ravichandran et al. [17], Dai et al. [18], Shlash \& Alhamdani [19], Mohammad \& Alhamadani [20], Hu [21],
Rahman et al. [22], Shpëtim [23], Zafar et al. [24], Ramseook-Munhurrun [25], Madjid et al. [26], Sarker and Islam [66], Arfaeian \& Chaipoopirutana [67], Rasheed \& Eternal [68], and Chou [69].

From the description of the theoretical and empirical findings of the above it can be concluded that service quality has a positive relationship with satisfaction, trust, commitment and customer loyalty. Because of it, the propositionscan be formulated as follows:

P1a Quality of service has a positive relationship with customer satisfaction

P1b Quality of service has a positive relationship with customer trust

P1c Quality of service has a positive relationship with customer commitment

P1d Quality of service has a positive relationship with customer loyalty.

\subsection{Relationship of Price Perception with Satisfaction, Trust, Commitment and Loyalty}

Price is an important factor of customer satisfaction, because every time a consumer evaluate the value of a product or service that is acquired, they usually think of the price [28,70,71,72,73]. Zeithaml \& Bitner [56] showed that the level of satisfaction is subject to the factors of quality of service, product quality, price, situation, and personal factors. According to Zeithaml [70] prices is something that must be sacrificed to get some kind of product or service from conception cognitive consumers. Typically, the lower the perceived price, the lower the perceived sacrifice. Prices are in accordance with the quality of products or services as well as customer expectations will arouse their desire to believe, committed and loyal to the products or services offered.

Some empirical findings that show the relationship between the perception of price satisfaction, trust, commitment and loyalty among customers is the result of research conducted by Bolton et al. [32], Cronin et al. [28], Sarker and Islam [66], Yeboah et al. [46]. From the description of the theoretical and empirical findings of the above it can be concluded that the perception of the price has a positive relationship with satisfaction, trust, commitment and customer loyalty. So, the propositions can be formulated as follows:

P2a price perception has a positive relationship with customer satisfaction

P2b price perception has a positive relationship with customer trust

P2c price perception has a positive relationship with customer commitment

P2d price perception has a positive relationship with customer loyalty

\subsection{Relationship of Value Perceptions with Satisfaction, Trust, Commitment, and Customer Loyalty}

Customer satisfaction is a comparison between acceptable performance with expectations, where customer satisfaction depends on the perception of customer value itself 
[74]. The higher the value of the attribute received by customers increased, their satisfaction with the service provider will also increase. Therefore it can be said there is a positive and significant relationship between perceived value and customer satisfaction [75,76,77]. Consumer perceived value can build relationships with consumers, the company's credibility, trust, and customer loyalty. Similarly, there is the influence of values, loyalty, and profit. The higher the perceived value the higher the profit earned loyalty and customer [78].

If the customer assessment is good, then the customer will be satisfied, moreover, they will reuse (repeat customer), promoting word of mouth to friends, relatives and acquaintances, and have immunity over competing bids (Griffin, 1995) of the value of outstanding service will create customer loyalty to the company. By creating customer value every day and every moment, will increase loyalty. Therefore, it can be said that the level of customer loyalty is influenced by consumers' perceptions of the value offered by the company [79].

Some empirical findings that show the relationship between perceived value and satisfaction, trust, commitment and loyalty among customers is the result of research conducted by Roig et al. [80], Hatane and Wijaya [62], Anuwichanont \& Mechinda [81], Deng et al. [65], Yee \& Faziharudean [64], Khan [82], Rudyanto [10], Jumaev et al. [83], Rashed \& Eternal [84], as well as Arfeian \& Chaipoopirutana [67].

From the description of the theoretical and empirical findings of the above it can be concluded that the perception of value has a positive relationship with satisfaction, trust, commitment and customer loyalty. So, thepropositions can be formulated as follows:

P3a perception of value has a positive relationship with customer satisfaction

P3b perception of value has a positive relationship with customer trust

P3c perception of value has a positive relationship with customer commitment

P3d perception of value has a positive relationship with customer loyalty.

\subsection{The Relationship of Brand Equity with Satisfaction, Trust, Commitment and Loyalty}

A brand that has equity means addressed positively by consumers. A positive attitude will also encourage the formation of loyalty $[85,86]$, which allows the purchase of a recurring basis. Strong brands attract consumers to use brands factor in making purchasing decisions. Strong brand equity will shape customer expectations towards prosuk and services offered. Further evaluation of post-consumption customers will determine their level of satisfaction or dissatisfaction. But many empirical findings show that brand equity has a close relationship with customer satisfaction. Similarly, the experience gained customer satisfaction on consumer products and services that have a strong brand equity, will establish trust and their commitment to products and services.

Some empirical findings that show the relationship between brand equity with satisfaction, trust, commitment and loyalty among customers is the result of research conducted by Ahmad and Hashim [38], Hu [21], Nam et al. [87], Nemati \& Anees [44], Yeboah et al. [46], Dlačić \& Kezman [40], Saeednia \& Masoumi [41], Nourali et al. [45] and Katigari \& Monsef [42].

From the description of the theoretical and empirical findings of the above it can be concluded that brand equity has a positive relationship with customer satisfaction. So, the propositions can be formulated as follows:

P4a Brand equity has positive relationship with customer satisfaction

P4b Brand equity has positive relationship with customer trust

P4c Brand equity has positive relationship with customer commitment

P4d Brand equity has positive relationship with customer loyalty.

\subsection{The Relationship of Trust with the Customer Satisfaction, Commitment and Customer Satisfaction}

Trust in a brand is formed by a certain period after the consumer feel the satisfaction gained from the advantages and benefits obtained after consuming a product. Consumer confidence in the brand gained after positive emotional closeness of the relationship between companies and consumers. Satisfaction with the service provided is a device that increases the spirit of cooperation. Therefore there is a significant relationship between satisfaction with the commitment on a long-term relationship (Morgan \& Hunt, [50]. Bloemer \& Odekerken-Schroder [88] states, consumer satisfaction positive effect on their commitments, then the effect on consumer loyalty is. More specifically, Hennig-Thurau \& Klee [89], Hennig-Thurau et. al. [90], and Tax \& Brown [91] explained that consumers are satisfied will impact directly on commitments arising from within the consumer a high level of satisfaction that will direct consumers to create commitment and influence the emotional bond.

Satisfaction are the most important factors that influence customer loyalty [47,92]. In a long term relationship customers not only expect high quality of the main services but also the added benefit of continuing a relationship. Satisfied and loyal customers an opportunity to gain new customers through word of mouth recommendation. Customer satisfaction has a positive relationship and significant impact on customer loyalty [93]. More and more consumers meet their expectations for purchases or services are used, the higher the likelihood that the consumer will repeat purchases in the formation of the same [92].

Some empirical findings that show the relationship between satisfaction with trust, commitment and loyalty among customers is the result of research conducted by Hatane and Wijaya [62], Akbar \& Parvez [94], Roig et al. [80], Anuwichanont \& Mechinda [81], Brakus et al. [95], Deng et al. [65], Hamadi [63], Hsu et al. [94], Santouridis \& Trivellas [96], Rudyanto [10], Shpëtim [23], Lovblad et al. [97], Zafar et al. [34], Vuuren et al. [98], Hazra [99], Madjid et al. [26], Agyei \& Kilika [100], as well as Arfaeian \& Chaipoopirutana [67]. From the description of the theoretical and empirical findings of the above it can be concluded that satisfaction has a positive relationship 
with trust, commitment and customer loyalty. So, the propositions can be formulated as follows:

P5a Customer satisfaction has a positive relationship with customer trust

P5b Customer satisfaction has a positive relationship with customer commitment

P5c Customer satisfaction has a positive relationship with customer loyalty.

\subsection{The Relationship of Trust with Commitment and Customer Loyalty}

Consumer confidence in the service providers will increase the value of the relationship with the service provider. Ramsey and Sohi [101] suggests that trust is an important element that affects the quality of a relationship. Therefore, the more confidence as the variable that precedes the commitment [102]. Morgan \& Hunt [50] add that high trust will be an effect on decreasing the possibility to transfer to another service provider. Correspondingly, Kurniasari and Ernawati (2012) argued that trust is a fundamental part to the formation of commitments, and commitments have a tendency to fight preferences become a key pioneer for loyalty.

Some findings empirically that shows the relationship between the trust with the commitment and loyalty of which is the result of research conducted by Wang [103], Hatane and Wijaya [62], Anuwichanot \& Mechinda [81], Lita [104], Deng et al. [65], Yee \& Faziharudean [64], Hsu et al. [94], Kuppelwiesser et al. [105], Rudyanto [10], Lovbland et al. [97], Jumaev et al. [83], Vuuren et al. [98], Shpëtim [23], Amin et al. [106], Madjid et al. [26], Rasheed \& Eternal [68], Hazra [99], Arfaeian \& Chaipoopirutana [67], and Chou [69]. From the description of the theoretical and empirical findings of the above it can be concluded that the trust customers have a positive relationship with commitment and customer loyalty. So, the propositions can be formulated as follows:

P6atrust have a positive relationship with customer commitment

P6btrust have a positive relationship with customer loyalty

\subsection{The relationship of Customer Commitment to Customer Loyalty}

Linkages commitment and customer loyalty proposed by Nielsen (1998), that an increased commitment will affect the increased customer loyalty. This is understandable, given the high commitment to make the customer maintain good relations have been established with service providers.

Some empirical findings that show the relationship between customer commitment to customer loyalty among which are the result of research conducted by Roig et al. [80], Lita [104], Marshall [107], Jones et al. [108], Dagger et al. [109], Dai et al. [18], Jumaev et al. [83], Vuuren et al. [98], Madjid et al. [26], Martini [110], Lariviere et al. [111].

From the description of the theoretical and empirical findings of the above it can be concluded that the commitment to the customer has a relationship with customer loyalty. So, the proposition can be formulated as follows:

P7 customer commitment has a positive relationship with customer loyalty

\section{Conclusion}

Loyal customer is one key to the success of a service company. Forming a loyal customer is an important thing for company management. Attempts to get a loyal customer has been studied empirically. Through this article, the authors attempt to identify the various factors that are determinants of customer loyalty in the service industry. From the foregoing discussion, it is known that service quality, perceived price, customer perceived value, brand equity, customer satisfaction, customer trust and customer commitment are the primary determinants of customer loyalty in the service industry. This shows that in order to establish customer loyalty, initiated through the provision of quality services, reasonable pricing, create and provide good value for customers, as well as creating a positive brand equity. These efforts will bring satisfaction to the customers in the short term, and will further lead to trust and commitment from them, both for services and companies. Continuously, trust and commitment will establish customer loyalty. Through the loyal customers, the company will get benefit in long term. Therefore, managers need to give more attention to efforts to get a loyal customer.

\section{References}

[1] Daft, Richard L., 2007. Management, Terjemahan Edward Tanujaya dan Shirly Tiolina, Jakarta:Salemba Empat.

[2] Berger, P.D. and N.I. Nasr, 1998. Customer Lifetime Value: Marketing Models and Applications, Journal of Interactive Marketing, Vol. 12 (Winter), pp. 17-30.

[3] Bolton, R.N., 1998. A dynamic model of the duration of the customers' relationship with a continuous service provider: The role of customer satisfaction. Marketing Science, 17(1), 45- 65.

[4] Aksoy, S. Atilgan, E., Akinci, S., 2003, Airline Services Marketing by Domestic and Foreign Firms: Differences From The Customers' Viewpoint. Journal of Air Transport Management, 9, 6, 343-351.

[5] Aaker, David.A., 1991. Managing Brand Equity: Capitalizing on the Value of Brand Name, New York: The Free Press.

[6] Guiltinan, J.P., Paul, G.W. and MaidenT.J., 1997. Marketing Management: Strategies and Programs,New York: The McGrawHill Companies, Inc.

[7] Reichheld, F. and W.E. Sasser, Jr., 1990. Zero Defections: Quality Comes to Services, Harvard Business Review, Vol. 68, September-October, 105-111.

[8] Castro, C.B., and Armario, E.M., 1999. Marketing relacional. ESIC Editorial.

[9] Shergill, G.S. and Li, Bing, 2006. Internet Banking-An Empirical Investigation of a Trust and Loyalty Model for New Zealand Banks, Journal of Internet Commerce, 4: 4, 101-118.

[10] Rudyanto, 2011. Pengaruh Kepercayaan, Kepuasan Pelanggan, Persepsi Nilai Terhadap Komitmen dan Loyalitas Pelanggan Melalui Layanan Elektronik (e-Service) Usaha Wisata.

[11] Fornell, C., Johnson, M.D., Anderson, E.W., Cha, J., and Bryant, B.E., 1996. The American Customer Satisfaction Index: Nature, Purpose and Findings,Journal of Marketing, 60(4), 7-18.

[12] Lassar, W., Mittal, B. and Sharma, A., 1995. Measuring Customer-Based Brand Equity, Journal of Consumer Marketing, Vol. 12, No. 4, 11-19. 
[13] Knox, S., \& Walker, D., 2001. Measuring and Managing Brand Loyalty, Journal of Strategic Marketing, 9(2), 111-128.

[14] Clottey, T. A., Collier, D. A., and Stodnick, M., 2008. Drivers of Customer Loyalty in a Retail Store Environment, Journal of Service Science, 1(1), 35-48.

[15] Johnson, M.D., Herrmann, A. and Huber, F., 2006. The Evolution of Loyalty Intentions,Journal of Marketing, 70(2), 122-132.

[16] Rial, A., Rial, J., Varela, J., and Real, E. 2008. An application of importance-performance analysis (IPA) to the management of sport centres. Managing Leisure, 13(3-4), 179-188.

[17] Ravichandran, K., Mani, Tamil B., Kumar, S. Arun and Prabhakaran, S., 2010. Influence of Service Quality on Customer Satisfaction Application of Servqual Model, International Journal of Business and Management, Vol. 5, No. 4; April 2010.

[18] Dai, Hua., Haried, Peter., and Salam, A.F., 2011. Antecedents of online service quality, commitment and loyalty, Journal of Computer Information Systems, Winter 2011.

[19] Shlash Mohammad, A. A., \& Mohammad Alhamadani, S. Y. 2011. Service Quality Perspectives and Customer Satisfaction in Commercial Banks Working in Jordan. Middle Eastern Finance and Economics, 1(14), 60-72.

[20] Mohammad, Anber Abraheem Shlash and Alhamadani, Shireen Yaseen Mohammad, 2011. Service Quality Perspectives and Customer Satisfaction in Commercial Banks Working in Jordan, Midle Eastern Finance and Economics, Issue 14, 60-72.

[21] Hu, Yu-Jia., 2011. How Brand Equity, Marketing Mix Strategy And Service Quality Affect Customer Loyalty: The Case of Retail Chain Stores in Taiwan, The International Journal of Organizational Innovation, Vol. 4 No. 1 (Summer), 59-73.

[22] Rahman, M.S., Khan, Abdul Highe, and Haque, Md. Mahmudul, 2012. A conceptual study on the relationship bertween Service Quality towards Customer Satisfaction: Servqual and gronroos's Service Quality Model Perspective, Asian Social Science, Vol. 8, No. 13, 201-210.

[23] Shpëtim, Çerri., 2012. Exploring the Relationships among Service Quality, Satisfaction, Trust and Store Loyalty among Retail Customers, Journal of Competitiveness, Vol. 4, Issue 4, 16-35.

[24] Zafar, Mohsin, Zafar Sana, Asif Aasia Hunjra, Ahmed Imran and Ahmad H. Mushtaq, 2012. Service Quality, Customer Satisfaction and Loyalty: An Empirical Analysis of Banking Sector in Pakistan, Information Management and Business Review, Vol. 4, No. 3, 159-167.

[25] Ramseook-Munhurrun, 2012. Perceived service quality in restaurant services, Global Conference on Business and Finance Proceedings, Vol. 7, No. 1.

[26] Madjid, Rahmad., Hadiwidjojo, Djumilah., Surachman, dan Djumahir, 2013. The Role of Customer Trust and Commitment as Mediator for The Relation Between Customer Satisfaction and Loyalty at BRI Kendari Southeast Sulawesi,International Journal of Business and Management Invention, Vol. 2, Issue 4, 53-64.

[27] Oliver, R. L., 1997. A Cognitive Model of The Antecedents and Consequences of Satisfaction Decisions, Journal of Marketing Research, vol. 17, No.4, Nopember, 460-469.

[28] Cronin, J.J., Brady, M.K. and Hult, G.T.M., 2000. Assessing the Effects of Quality, Value, and Customer Satisfaction on Consumer Behavioral Intentions in Service Environments, Journal of Retailing, Vol. 76, No. 2, 193-218.

[29] Homburg, C., Koschate, N., and Hoyer, W.D., 2005. Do satisfied customers really pay more? A study of the relationship between customer satisfaction and willingness to pay. Journal of Marketing, 69(2), 84-96.

[30] Athanassopoulos, A.D., 2000. Customer Satisfaction Cues to Support Market Segmentation and Explain Switching Behavior. Journal of Business Research, 47, 191-207.

[31] Voss, G. B., Parasuraman, A. and Grewal, D., 1998. The Roles of Price Performance, and Expectations in Determining Satisfaction in Service Exchanges, Journal of Marketing, 62 (4), 46-61.

[32] Bolton, Ruth N., Kannan, P. K., Bramlett, Mathew D.,2000. Implication of Loyalty Programs and Service Experiences for Customer Retention and Value, Journal of the Academy of Marketing Science, 28 (1) 95-108.

[33] Andreassen, Tor Walin and Lindestad, Bodil, 1998, Customer Loyalty and Complez Services, International Journal of Service Industry Management, Vol. 9 (1), 7-23.

[34] Peter, Paul J., and Jerry C. Olson, 1990. Customer Behavior and Marketing Strategy, Terjemahan Damos Sihombing, Jakarta: Erlangga.
[35] Sheth, J.N., Newman, B., and Gross, B., 1991. Consumption Values and Market Choices: Theory \& Application. Cincinnati: South-Western Publishing Co.

[36] Alghifari, Ahmad Kholid, 2009. Analisis Pengaruh Brand Equity Terhadap Pembentukan Customer Loyality Pada Jenis Merek Pasta Gigi Dengan Analisis SEM, Symposium Nasional RAPI VIII, Hal. 58-65.

[37] Rangkuti, Freddy., 2002.The Power of Brands, Jakarta: Gramedia.

[38] Ahmad, Zamri and Hashim, Rahmat, 2010, Customer's Brand Equity and Customer Loyalty: a Study on Hotel's Conference Market, World Applied Sciences Journal, 10 (Special Issue of Tourism \& Hospitality) 115-120.

[39] Hu, Yu-Jia., 2011. How Brand Equity, Marketing Mix Strategy And Service Quality Affect Customer Loyalty: The Case of Retail Chain Stores in Taiwan, The International Journal of Organizational Innovation, Vol. 4 No. 1 (Summer), 59-73.

[40] Dlačić, Jasmina and Kežman, Elvedina, 2014, Exploring Relationship Between Brand Equity And Customer Loyalty On Pharmaceutical Market, Economic And Business Review, Vol. 16, No. 2, 121-131.

[41] Saeednia, Hamid Reza and Masoumi, Parinaz, 2014, An Investigation on the Effects of Brand Equity, Trust, Image and Customer Satisfaction on Regular Insurance Firm Customers' Loyalty, Management Science Letters 4, 497-502.

[42] Katigari, Mohammad Javad Asadi and Monsef, Seyyed Mahmood Shabgoo, 2015, Investigation the Relationship Between Brand Equity, Customer Satisfaction and Customer Loyalty (Case study: Restaurants of RASHT), GMP Review, Vol. 16(3), 467-472.

[43] Nam J, Ekinci Y, Whyatt G., 2011. Brand equity, brand loyalty and consumer satisfaction, Annals of Tourism Research, 38(3): 1009-1030.

[44] Nemati A.R, and Anees A.N., 2012. Determinants of Brand Management and its Impact on Customer Satisfaction: Evidence from Islamic Banking Sector of Pakistan, Proceedings of World Islamic Banking, Finance and Investment Conference, Kualalumpur, 17 - 18 December 2012, 1-16.

[45] Nourali, Mohamad Reza, Touran Razmavar, and Zahra Mansouri, 2014. The Impact of customer relationship management, brand equity and employee development on Customer Satisfaction: The study of banks branches of the city Boushehr, International Journal of Management and Humanity Sciences. Vol., 3 (9), 3117-3123.

[46] Yeboah, Asiamah; Owusu-Mensah, Samuel; Nimsaah, Wilson Kwaku, and Mensah, Nicholas Oppong, 2013, The Effect Of Brand Name On Customer Loyalty In The Mobile Communication Industry In Ghana, British Journal of Marketing Studies, Vol.1, No.3 (September), 62-86.

[47] Assael, Henry, 2004.Consumer Behavior, Ohio : Thomson South Western College Publishing.

[48] Verhoef, Peter C., 2003. Understanding the Effect of Customer Relationship Management Effort on Customer Retention and Customer Share Development, Journal of Marketing, Vol. 67 (October), 30-45.

[49] Mittal, B., 2004. Lack of Attribute Searchability: Some Thoughts, Psychology and Marketing, Vol. 21, No. 6 (July), 443-462.

[50] Morgan, R.M., and Hunt, S.de., 1994. The Commitment-Trust Theory of Relationship Marketing, Journal of Marketing, Vol 58, 20-38.

[51] Singh, Jagdip and Deepak Sirdeshmukh, 2000. Agency and Trust Mechanisms in Relational Exchanges, Journal of the Academy of Marketing Science, 28 (Winter), 150-167.

[52] Nicholson, Carolyn Y., Larry D. Compeau, and Rajesh Sethi, 2001. The Role of Interpersonal Liking in Building Trust in Long-Term Channel Relationships," Journal of the Academy of Marketing Science, 29 (1) 3-15.

[53] Floh, Arne and Treiblmaier, H., 2006. What Keeps the E-banking Customer Loyal? Multi-group Analysis of the Moderating Role of Consumer Characteristics on E-loyalty in the Financial Service Industry. Journal of Electronic Commerce Research, 7 (2), 97-110.

[54] Chu, P.Y., Lee, G.Y., and Chao, Y., 2012. Service quality, customer satisfaction, customer trust, and loyalty in an e-banking context. Social Behavior and Personality: an international journal, 40(8), 1271-1283.

[55] Buttle, F., 1996. SERVQUAL: Review, Critique, Research Agenda, European Journal of Marketing, Vol. 30, No. 1, 8-32.

[56] Zeithaml, V.A. and Bitner, M.J., 1996.Service Marketing, New York : McGraw-Hill Companies, Inc. 
[57] Gotlieb, J.B., Grewal, D., and Brown, S.W., 1994. Consumer satisfaction and perceived quality: complementary or divergent constructs?. Journal of applied psychology, 79(6), 875.

[58] Lee, H., Lee, Y., and Yoo, D., 2000. The determinants of perceived service quality and its relationship with satisfaction. Journal of services marketing, 14(3), 217-231.

[59] Caruana, A., and Malta, M., 2002. Service Loyality the Effects of Service Quality and the Mediating Role of Customer Satisfaction, European Journal of Marketing, 36(8), 811-828.

[60] Fullerton, G., and Taylor S., 2002. Mediating, Interactive, and Non-Linear Effects in Service Quality Satisfaction With Research, Journal of Marketing 12(2): 124-136.

[61] Hadioetomo, 2009. Analisis Kualitas Layanan yang Mempengaruhi Kepuasan Pelanggan serta Dampaknya Terhadap Behavioral Intensions, Karisma, Vol 3(2), 113-122.

[62] Hatane, Semuel dan Wijaya, Nadya., 2009. Service Quality, Perceived Value, Satisfaction, Trust dan Loyalty Pada PT Kereta Api Indonesia Menurut Penilaian Pelanggan Surabaya, Jurnal Manajemen Pemasaran, Vol. 4, No. 1, April 2009: 23-37.

[63] Hamadi, Chakib., 2010. The Impact of Quality of Online Banking on Customer Commitment, Publishing Communications of the IBIMA, Vol. 2010.

[64] Yee, Beh Yin and Faziharudean, T.M., 2010. Factors affecting customer loyalty of using Internet banking in Malaysia. Journal of Electronic Banking Systems, 21.

[65] Deng, Zhaohua., Lu, Yaobin., Wei, Kwok Kee., and Zhang, Jinlong., 2010. Understanding Customer Satisfaction and Loyalty : An Empirical Study of Mobile Instant Messages in China, International Journal of Information Management, 30, 289-300.

[66] Sarker, Mohammad Sumann and Islam, Rabiul, 2013. Competitive arket of Air Industry and Competitive Advantages for Customer Satisfaction through Pricing Strategy of Air-Asia, Journal of Applied Sciences research, 9(4), 2505-2512.

[67] Arfaeian, Firouzeh and Chaipoopirutana, Sirion., 2014. A Study of the Antecedent of Brand Trust: A Case Study of Low Cost Airline in Bangkok, Thailand.

[68] Rasheed, Firend A. and Abadi, Masoumeh F., 2014. Impact of Service Quality, Trust and Perceived Value on Customer Loyalty in Malaysia Services Industries.

[69] Chou,Pin-Fenn., 2014. An Evaluation Of Service Quality, Trust, and Customer Loyalty in Home-Delivery Services, International Journal of Research In Social Sciences, Vol. 3, No.8 April.

[70] Zeithaml V.A., 1988. Consumer Perceptions of Price, Quality, and Value: A Means-end Model and Synthesis of Evidence. Journal of Marketing 52(1), 2-22.

[71] Fornell, C. 1992. A National Customer Satisfaction Barometer: The Swedish Experience, Journal of Marketing, Vol.56 (January), 6-21.

[72] Anderson, James C., Hakan Hakansson, and Johanson, Jan, 1994. Dyadic Business Relationships Within a Business Network Context, Journal of Marketing, Vol. 58, 1-15.

[73] Anderson, Eugene.W. and Mary,Sullivan.1993, "The Antecedents and Consequences of Customer Satisfaction for Firms," Journal of Marketing Science, Vol.12 (Spring), pp.125-143.

[74] Lin, Chia-Chi, 2003. Customer Perceived Value and Customer Satisfaction: An E-business Perspective, Journal of Research in Marketing and Entrepreneurship, Volume Five, Issue 1, 25-39.

[75] Cronin, J.J. and Taylor, S.A., 1992. Measuring Service Quality: A Reexamination and Extension, Journal of Marketing, Vol. 56 (July), 55-68.

[76] Lai, T.L., 2004. Service quality and perceived value's impact on satisfaction, intention and usage of short message service (SMS). Information Systems Frontiers, 6(4), 353-368.

[77] Palilati, Alida., 2007. Pengaruh Nilai Pelanggan, Kepuasan terhadap Loyalitas Nasabah Tabungan Perbankan di Sulawesi Selatan, Jurnal Manajemen dan Kewirausahaan, Vol. 9, No. 1, Maret 2007: 73-81.

[78] Robinette, S., Brand, C., and Lenz, V., 2001. Emotion marketing. New York.

[79] Gale, B., 1997. Customer satisfaction - relative competitors - is where it's at. (Strong evidence that superior quality drives the bottom line and shareholder value), Marketing and Research Today, 3953.

[80] Roig, Juan Carlos Fandos., Garcia, Javier Sanches and Tena, Miguel Angel Moliner., 2009. Perceived Value and Customer Loyalty in Financial Services, The Service Industries Journal, 29, 6, 775-789.
[81] Anuwichanont, Jirawat and Mechinda, Panisa., 2009. The Impact of Perceived Value on Spa Loyalty and Its Moderating Effect of Destination Equity, Journal of Business and Economic Research, Vol. 7 No. 12, 73-89.

[82] Khan, Nasreen, 2010, Functional And Relational Value Influence On Commitment And FutureIntention: The Case Of Banking Industry, Uluslararasi Sosyal Araştirmalar Dergisi (The Journal Of International Social Research),Volume: 3 Issue: 10 Winter 2010, Pp. 376-391.

[83] Jumaev, Mukhiddin;, Dilep, Kumar M., Hanaysha, Jalal R.M., 2012. Impact of Relationship Marketing on Customer Loyalty in the Banking Sector, Far East Journals of Psychology and Business, 36-55.

[84] Rasheed, F.A., and Abadi, M.F., 2014. Impact of service quality, trust and perceived value on customer loyalty in Malaysia services industries. Procedia-Social and Behavioral Sciences, 164, 298-304.

[85] Keller, Kevin L., 2008.Strategic Brand Management, Englewood Cliffs, New Jersey: Prentice Hall.

[86] Cheverton, P., 2004. Key Account Management in the Financial Services Industry. Kogan Page Publishers.

[87] Nam J, Ekinci Y, Whyatt G., 2011. Brand equity, brand loyalty and consumer satisfaction, Annals of Tourism Research, 38(3): 1009-1030.

[88] Bloemer, J. and Oderkerken-Schroder, G., 2003. Antecedents and Consequences of Affective Commitment, Australasian Marketing Journal, 11(3), 33-43.

[89] Hennig-Thurau, Thorsten and Klee, Alexander., 1997. Impact of Customer Satisfaction and Relationship Quality on Customer Retention - A Critical Reassessment and Model Development, Psychology and Marketing, Vol.14 (December), 737-765.

[90] Hennig-Thurau, Thorsten., Gwinner, Kevin P. and Gremler, Dwayne D., 2002. Understanding Relationship Marketing Outcomes: An Integration of Relational Benefits and Relationship Quality, Journal of Service Research, February, 230-247.

[91] Tax, S.S. and Brown, S.W., 1998. Recovering and learning from service failure. Sloan Management Review, 40 (1), 75-88.

[92] Wong, A., and Sohal, A., 2003. Service quality and customer loyalty perspectives on two levels of retail relationships. Journal of services marketing, 17(5), 495-513.

[93] Akbar,Mohammad Muzahid and Parvez, Noorjahan., 2009. Impact of Service Quality, Trust, and Customer Satisfaction on Customer Loyalty,ABAC Journal, Vol. 29, No. 1 (January-April), 24-38.

[94] Hsu, Chien-Lung., Liu, Chia-Chang and Lee, Yuan-Duen, 2010. Effect of Commitment and Trust Towards Micro-Blogs on Consumer Behavioral Intention: a Relationship Marketing Perspective, International Jurnal of Electronic Business Management, Vol. 8 No. 4, 292-303.

[95] Brakus, J.J., Schmitt, B.H., and Zarantonello, L., 2009. Brand experience: what is it? How is it measured? Does it affect loyalty? Journal of marketing, 73(3), 52-68.

[96] Santouridis, I., and Trivellas, P., 2010. Investigating the impact of service quality and customer satisfaction on customer loyalty in mobile telephony in Greece. The TQM Journal, 22(3), 330-343.

[97] Lovblad, Mikael, Hyder Akmal S. and Lonnstedt Lars, 2012. Affective commitment in industrial customer-supplier relations: a psychological contract approach, Journal of Business and Industrial Marketing, 27/4, 275-285.

[98] Vuuren, T. van., Roberts-Lombard, M. and Tonder,E. van., 2012. Customer Satisfaction, Trust and Commitment as Predictors of Customer Loyalty Within an Optometric Practice Environment.

[99] Hazra, Sandip Ghosh., 2013.An Investigating Into Customer Satisfaction, Customer Commitment and Customer Trust: A Study in Indian Banking Sector,International Refereed Research Journal, Vol. IV, Issue-1, January (96-102).

[100] Agyei, Paul Mensah and Kilika, James M., 2013.The Relationship between Service Quality and Customer Loyalty in the Kenyan Mobile Telecommunication Service Industry, European Journal of Business and Management, Vol. 5 No. 23, 26-36.

[101] Ramsey, R.P., and Sohi, R.S., 1997. Listening to your customers: The impact of perceived salesperson listening behavior on relationship outcomes. Journal of the Academy of marketing Science, 25(2), 127-137.

[102] Garbarino, Ellen and Johnson, Mark S., 1999. The Different Roles of Satisfaction, Trust, and Commitment in Customer relationships, Journal of Marketing, Vol. 63, April, 70-87. 
[103] Wang, Jau-Shyong, 2009. Trust and relationship commitment between direct selling distributors and customers, African Journal of Business Management, Vol.3 (12), pp. 862-870.

[104] Lita, Ratni Prima., 2009. Pengaruh Kepercayaan pada Komitmen Loyalitas Pelanggan,Trikonomika, Vol. 8 N0. 2, 71-77.

[105] Kuppelwieser, Volker G., Grefrath, Robert and Dziuk, Agathe 2011. A Classification of Brand Pride Using Trust and Commitment, International Journal of Business and Social Science, Vol. 2 No. 3 (Special Issue - January 2011).

[106] Amin, Salmiah Mohamad., Ahmad, Ungku Norulkamar Ungku and Hui, Lim Shu., 2012. Factors Contributing to Customer Loyalty Towards Telecommunication Service Provider, Procedia Social and Behavioral Sciences, 40, 282-286.

[107] Marshall, Norman W., 2010. Commitment, Loyalty and Customer Lifetime Value: Investigating the Relationship Among Key Determinants, Journal of Business and Econmic Research, Vol. 8, No. 8, 67-84.

[108] Jones, Tim., Fox, Gavin L., Taylor, Shirley F., and Fabrigar, Leandre R., 2010. Service Customer Commitment and Response, Journal of Business and Economics Research - December, Volume 7, Number 12
[109] Dagger, Tracey S., David, Meredith E. and Ng, Sandy., 2011. Do relationship benefits and maintenance drive commitment and loyalty?, Journal of Services Marketing, 25/4, 273-281.

[110] Martini, Luh Kadek., 2013. Relationship Marketing, Customer Commitment dan Customer Loyalty (Studi pada sebuah bank nasional di Denpasar),Buletin Studi Ekonomi, Vol. 18, No. 1, 9-25.

[111] Lariviere, Bart., Keiningham, Timothy L., Cooil, Bruce., Aksoy, Lerzan.,Malthouse, Edward C., 2014. A Longitudinal Examination of Customer Commitment and Loyalty, Journal of Service Management, Vol. 25 No. 1, 75-100.

[112] Dlačić, Jasmina and Žabkar, Vesna., 2012. Relationship Commitment, Relational Equity and Company Image in Customer Loyalty Development, Economic Research - Ekonomska Istraživanja, Vol. 25, No. 2, 503-524

[113] Virvilaite, Regina; Violeta Saladiene, Dalius Skindaras. 2009. The Relationship Between Price and Loyalty in Services Industry. ISSN 1392-2785. Inzinerine Ekonomika-Engineering Economics (3), 96-104. 